\title{
ISLAM DAN KUASA SEKSUALITAS PEREMPUAN DI INDONESIA
}

\author{
Tabrani. ZA'; Saifullah Idris ${ }^{2}$ \& Hayati $^{3}$ \\ 1,3Universitas Serambi Mekkah, Banda Aceh, Indonesia \\ ${ }^{2}$ Universitas Islam Negeri Ar-Raniry, Banda Aceh, Indonesia \\ ContributorEmail: tabraniza@scadindependent.org
}

\begin{abstract}
Abstrak
Gagasan yang menumbuh pada relasi kuasa tak ayal menumbuhkan bibit-bibit kekerasan seksual terhadap perempuan. Perempuan hanya dilihat sebagai seonggok daging bernama tubuh seksual. Subjek yang melihat adalah laki-laki. Melihat di sini dimaknai sebagai penguasa tatapan. Foucault menganasir hal ini sebagai tindakan kekuasaan-pengetahuan yang menerapkan strategi kekuasaannya untuk mengatur /seksualitas] perempuan. Ada histerisasi tubuh perempuan yang menunjukkan bahwa tubuh Iperempuanl dikaitkan dengan tubuh sosial untuk menjamin kesuburan dan semua bentuk kewajiban yang datang dari keluarga termasuk kehidupan anak. Jadi tubuh perempuan tidak bisa dilepaskan dari tanggung jawab biologi dan moral. Khasanah fikih klasik hingga hari ini masih memberikan kacamata patriarki yang sarat bias gender dalam mengatur seksualitas perempuan.
\end{abstract}

Keywords: Islam, Relasi Kuasa, Seksualitas, Perempuan

\section{Pendahuluan}

Tubuh perempuan selalu memasuki hiruk-pikuk pembahasan di segala ranah. Karenanya tidak ada diskursus lain yang memiliki daya tanding lebih yang mampu menyamai atau menyaingi diskursus ramai atasnya kecuali perbincangan tentang tubuh perempuan. Tubuh perempuan dari masa ke masa selalu mengalami kontestasi untuk diperebutkan oleh pihak-pihak yang berasal dari luar dirinya. Konstruksi sosial yang ditopang oleh ragam struktur sosial, berkembang setingkat dinamika yang mengiringi laju jaman. 
Ada titik yang dibidik sekaligus disasar dari perebutan wacana dan tubuh perempuan, yakni ketundukan dan kepasrahan. Dalam hal ini pihak laki-laki adalah tertuduh utama dengan bias sekaligus eros patriarkalnya, yang selalu merasa memiliki hak istimewa' untuk membuat berbagai penilaian atas tubuh perempuan. Laki-laki merasa seakan memiliki privilese untuk mengintervensi dengan meletakkan standar nilai tertentu kepada tubuh perempuan. Semuanya bekerja dalam bingkai patriarki yang mendudukkan posisi perempuan dan tubuhnya dalam posisi subordinat. Dimensi kekuasaan digunakan sebagai mesin kerja untuk mencapai tujuan.

Membicarakan seksualitas bagi sebagian masyarakat masih dianggap tabu secara normatif, meskipun pada kenyataannya hal itu merupakan tema pembicaraan yang menarik yang selalu diproduksi oleh masyarakat dalam berbagai bentuk wacana. Mulai dari perbincangan warung kopi sampai rumor di tingkat politisi. Apa sebenarnya yang dimaksud dengan seksualitas? Bagaimana Islam memandang seksualitas? Pengertian Seksualitas Apa yang terpikirkan saat mendengar kata seksualitas? Mungkin kita berpikir tentang seks. Pikiran kita tidaklah keliru. Namun seksualitas bukan hanya tentang seks. Seks dan seksualitas merupakan dua hal yang berbeda.

Seks berhubungan dengan masalah biologis pada perempuan dan lelaki, sementara seksualitas sangat luas cakupannya tidak hanya pada aspek biologis semata. Seksualitas adalah tentang bagaimana seseorang mengalami, menghayati dan mengekspresikan diri sebagai makhluk seksual, dengan kata lain tentang bagaimana seseorang berpikir, merasa dan bertindak berdasarkan posisinya sebagai makhluk seksual.

Segala sesuatu yang ada kaitannya dengan seks (ada kaitan dengan kelamin) tercakup di dalamnya. Hubungan seks hanyalah 
salah satu aspek, namun secara umum seksualitas memang selalu dihubungkan dengan hubungan seks (persetubuhan). Seksualitas merupakan konsep dan konstruksi sosial terhadap nilai dan perilaku yang berkaitan dengan seks, maka konsep seksualitas akan berbeda menurut tempat dan waktu. Perbedaan ini bukan hanya dalam makna seksualitas antar kebudayaan, tetapi juga dalam pemaknaan yang ada dalam budaya itu sendiri. Hal ini menurut Saptari yang dikutip dari Truongh karena diskursus seksualitas mengatur tiga dimensi kehidupan manusia yang meliputi: pertama, dimensi biologis yaitu yang menyangkut kegiatan seks sebagai kenikmatan biologis atau untuk mendapatkan keturunan.

Kedua, dimensi sosial yang meliputi hubungan-hubungan antara individu yang melakukan hubungan seks secara sah atau tidak sah (menurut ukuran masyarakat yang bersangkutan). Ketiga, dimensi subjektif yang berhubungan dengan kesadaran individu terhadap seksual diri sendiri atau kelompok. Dengan batasan yang begitu luas, seksualitas menjadi sebuah diskursus yang menyangkut perilaku jenis kelamin sekaligus sebagai seperangkat gagasan yang membentuk norma. Keduanya saling berhubungan satu sama lain. Apabila ditelaah dan diteliti, seksualitas merupakan sebuah konsep, kontruksi sosial terhadap nilai, orientasi, perilaku yang berkaitan dengan seks. Contohnya, perempuan dianggap melanggar sesuatu nilai kalau ia melahirkan tanpa suami. Contoh lain, laki-laki dalam pandangan masyarakat harus jantan dan dalam berprilaku seksual harus agresif. Maka bila perempuan yang agresif akan dianggap menyalahi konstruksi sosialnya dan menjadi aib. Permasalahan yang mendasar dalam seksualitas terjadi karena hubungan perempuan dan laki-laki tidak seimbang. 
Tabrani ZA, Saifullah Idris \& Hayati

Hubungan jender dan pemahaman seksualitas sebagai konstruksi sosial dalam masyarakat dipandang sebagai kodrat. Dengan demikian, jika hak reproduksi adalah hak setiap orang untuk membuat keputusan yang berhubungan dengan reproduksi yang bebas dari diskriminasi, paksaan dan kekerasan, maka kegiatan yang berhubungan dengan proses reproduksi yaitu hubungan seksual, juga harus bebas dari paksaan, kekerasan dan diskriminasi. Kemudian bagaimana ajaran Islam memandang seksualitas menjadi topik yang akan dibicarakan selanjutnya.

\section{Aurat dan Fitnah sebagai Dinding Pembatas}

Aurat selalu menjadi benteng penghalang bagi perempuan untuk mengekspresikan seksualitasnya, ditambah lagi wanita adalah "fitnah" bagi laki-laki. Hadist yang mengatakan perempuan adalah fitnah adalah" Aku tidak meninggalkan, setelah aku mati, suatu fitnah yang lebih mencelakakan laki-laki kecuali perempuan" (H.R. Bukhari). Pemahaman umum atas hadits ini sangat bias gender. Dengan dasar pemahaman "fitnah" yang sempit dan bias, wanita selalu dijadikan sumber malapetaka.

Perempuan diposisikan sebagai sesuatu yang membahayakan laki-laki. Pemerkosaan, tindakan kekerasan yang diterima oleh perempuan, menjadi salah perempuan atau korban yang notabene adalah perempuan. Alasan yang digunakan untuk menyalahkan perempuan adalah karena sebagai sumber fitnah. Perempuan yang tidak berhijab dan mengenakan pakaian yang mengumbar nafsu syahwat laki-laki, dianggap sebagai faktor penyebab pelecehan seksual.

Pemaknaan terminologi fitnah ini yang perlu dikaji lebih dalam. Secara genuin fitnah memiliki makna ujian. Dalam hal ini, artinya 
bukan wanita saja yang bisa menjadi ujian bagi laki-laki. Banyak hal yang dapat menjadi ujian dalam kehidupan. Hal tersebut berlaku bagi laki-laki maupun bagi perempuan. Sebab itu, kita juga bisa melihat kebalikan dari sudut pandang itu, bahwa laki-laki menjadi ujian bagi perempuan. Kalau hanya melihat perempuan sebagai fitnah, maka sudah jelas pemaknaan fitnah tersebut sangat bias gender. Perempuan hanya dijadikan objek penderita. Ditambah lagi, pemaknaan fitnah itu merujuk pada perilaku jahat seperti kebohongan, hasutan, penggoda dan hal jelek lainnya.

Berkat situasi di atas, hingga saat ini kita bisa melihat bahwa perempuan memiliki keterbatasan di ruang publik. Sistem patriarki yang mengakar memberikan batasan bagi ruang gerak perempuan. Sebagian besar tafsiran agama Barat menempatkan perempuan pada titik yang diapresiasi namun dibungkam dalam ruang yang sempit, hanya pada sektor domestik.

Padahal bila kita mencoba mencari beberapa kisah, bagaimana kedudukan perempuan pada zaman nabi, perempuan memiliki tempat di ruang publik. Pada zaman nabi, masih ada yang perempuan ikut dalam berbagai perdebatan beserta laki-laki untuk mengkaji berbagai permasalahan sosial di mesjid ataupun di ruang publik. Perempuan pada saat itu diberi hak oleh nabi untuk menjalankan ibadah personalnya di mesjid bersama laki-laki. Nabi mengatakan "Jangan halangi kaum perempuan pergi ke masjid".

Menurut Imam Bukhari, ketika Rasul tidak ada, Siti aisyah dan Ummu Salim menggulung pakaian hingga betis mereka untuk memberi minum para tentara yang sedang kehausan. Selain itu pada saat itu para perempuan ikut berpolitik dan berdiskusi dengan para laki-laki untuk membicarakan strategi perang, tanpa hijab. Tak sedikit 
dari para perempuan yang menggunakan pakaian yang disiapkan untuk perang; wajah,tangan dan kaki terbuka.

Bahkan, jika kita melihat lagi persoalan "suara" perempuan yang dibungkam di jaman sekarang, rupanya itu tidak sejalan juga dengan apa yang terjadi di zaman nabi. Kalau kita tengok cerita Khansa Bint Amr, seorang penyair puisi terkemuka di Arab, dia pernah membaca puisi di depan Nabi dengan penuh ekspresif. Nabi mengagumi sekaligus memuji beliau.

\section{Dinamika Perspektif Seksualitas seiring perkembangan Islam di Indonesia}

Mari kita bersama-sama menarik ke belakang tentang proses masuknya Islam ke nusantara sejak abad ke-13 dan perspektif yang digunakan dalam memandang perempuan. Gusdur membagi proses itu dalam beberapa babak sejarah. Babak pertama Islam Sufisme, babak kedua Islam Fiqh Sufistik dan babak ketiga Islam Fiqh. Babak Islam sufisme adalah pembabakan Islam yang mengutamakan essensialik atau mengedepankan apresiasi keberagaman budaya (Multikultural).

Hal ini dicontohkan dalam proses cross culture dengan cara kawin mawin antara pedagang dari Gujarat dengan warga nusantara. Atau oleh Wali Songo yang menggunakan pendekatan kultural. Pada masa Wali Songo perempuan ditempatkan pada posisi sesuai kondisi sosial budaya kultur masa itu. Pada saat itu memang perempuan berada di ruang domestik dan memang sudah sejak lama perempuan ada di ruang domestik.

Contoh perempuan yang masih ada di ruang domestik adalah ketika kegiatan syukuran dilaksanakan. Para laki-lakilah yang melaksanakan kegiatan tersebut, mereka berdoa kemudian dijamu, membakar tembakau dan ngobrol. Sedangkan para perempuan hanya 
dapat memasak, menyiapkan jamuan dan mengintip dari selasela bilik. (Geertz, 1981).

Di sisi lain perempuan pada masa itu diapresiasi dalam ritual. Dapat dilihat pada upacara adat seperti Seren Taun di Jawa Barat, Seblang di Banyuwangi, Bapalas Padang di Kalimantan Selatan dan Ngaturan Sari di Bali. Perempuan menjadi poros pada upacara-upacara tersebut. Perempuan mewakili dewi Sri, Nyi pohaci atau dewi bumi sebagai sumber kesuburan dan kemakmuran. Meskipun pada nyatanya legitimasi dan otoritas sang dewi sering dipinjam oleh raja setempat untuk menjalankan proyek-proyek kesuburan dan kesejahteraan rakyatnya.

Kemudian babak Islam Fiqh dimulai pada abad ke 20 ketika para pelajar Islam dari Timur Tengah, kembali ke tanah air. Babak Ini ditandai dengan berdirinya organisasi-organisasi Islam yaitu Sarekat Islam (SI), Nahdatul Ulama (NU), Muhamadiyah dan organisasi Islam lainnya. Babak ini lebih menekankan pada aspek legal formal dari institusi Islam. Meskipun pada kenyataannya Islam Fiqh ini melakukan dialektika dengan budaya Indonesia. Pada babak ini terlihat tetap ada corak fiqh Arab yang begitu kental di dalamnya.

Islam Fiqh ini dapat dikatakan sebagai Islam yang moderat. Islam Fiqh ini memiliki pandangan yang berada di tengah-tengah mahzab yang paling ekstrem di dalam Islam. Begitu juga halnya dengan isu seksualitas yang dipandang tidak terlalu ketat dan tidak terlalu longgar. Penganut kuat aliran Islam Fiqh adalah NU. Dapat dilihat dalam relasi seksualitas perempuan organisasi ini, perempuan diberikan ruang yang cukup luas untuk aktualisasi diri, meskipun tetap ada batas-batas yang mengikat. Misalnya mereka (nyai-nyai) diperbolehkan mengenakan kebaya dengan kerudung yang rambutnya terlihat. Sejak zaman dahulu para ulama dari golongan NU tidak pernah mengintimidasi perempuan 
yang berada di ruang publik atau melebeli mereka dengan cap tercela atau sesat.

Babak Islam Sufistik Fiqh tidak akan terlalu dibahas karena merupakan masa transisi antara Islam Sufistik dan Islam Fiqh. Kemudian belakangan muncullah Islam Fundamentalis. Aliran ini memberikan pandangan lain tentang seksualitas perempuan. Stigma mengenai perempuan kemudian muncul. Isu yang pertama kali muncul adalah jilbabisasi bagi kalangan perempuan muslim. Kemudian isu- isu lain tentang perempuan mulai muncul. Islam fundamentalis ini merupakan Islam yang dipengaruhi oleh teori keagamaan Islam Arab Saudi yang dikenal ketat, skriptual dan konservatif dalam urusan membatasi seksualitas perempuan. Islam Fundamentalis atau Islam garis keras ini berusaha mengembalikan Islam seperti abad pertengahan.

\section{Problem Seksualitas Perempuan dalam Ruang Publik}

Pengaruh Islam Fundamentalis ini tidak hanya terjadi di Indonesia namun bersifat transnasional. Indonesia yang sedang terpuruk mendapat imbas yang sangat kuat dari fenomena ini. Kelompok ini gencar mengampanyekan perempuan harus sangat tertutup dan mereka tidak memiliki hak berpolitik, meskipun punya hak berpolitik sangat dibatasi, karena mereka percaya dibalik laki-laki yang hebat terdapat perempuan yang shalehah.

Dapat dihitung dengan jari perempuan yang menjadi pemimpin daerah. Selalu ada cibiran kalau "fitrah" perempuan hanya untuk berada di dapur. Jangankan untuk berpolitik, bagi sebagian kelompok suara wanita adalah sebuah "fitnah".Bukankah hal yang aneh bila kemudian suara perempuan harus ditutuptutupi karena dianggap sebuah "aurat". Padahal seperti cerita di atas Nabi pernah mengapresiasi Khansa Bint Amr. 
Setelah sekian lama Islam moderat mendorong posisi perempuan untuk memiliki ruang di ranah publik, kini posisi seksualitas kembali terpinggirkan. Penyebab pemerkosaan, perselingkuhan hingga kekerasan pada perempuan lagi-lagi dikaitkan dengan kodrat perempuan yang harus menjaga aurat. Dari berbagai kasus pelecehan dan pemerkosaan, perempuanlah yang selalu disalahkan.

Banyak kalangan yang "meng-aminkan"isu yang mereka usung terutama isu seksualitas perempuan. Hal ini berpengaruh pada tatanan politik dan kebijakan pemerintah, seperti lahirnya undang-undang pornografi dan pornoaksi yang sangat bias beberapa waktu lalu. Selain itu banyak aturan-aturan pemerintah, baik dalam RUU atau sudah disahkan memiliki bias agama dan moralitas.

Kasus yang terakhir adalah pembunuhan dengan gagang pacul yang dilakukan terhadap buruh swasta oleh mantan kekasih dan temannya. Setelah kasus tersebut, beredar meme di media sosial dengan tulisan "Masih tidak menjaga aurat? Pacul masih banyak!" Meme tersebut mewakili kesadaran kolektif sebagian orang di Indonesia mengenai posisi seksualitas perempuan, bahwa perempuanlah yang menjadi penyebab kemaksiatan. Demikianlah wacana seksualitas yang terjadi di negeri Indonesia.

Kondisi ini bukan hanya membungkam perempuan di ruang sempit, namun menghilangkan potensi-potensi bangsa, kemanusiaan dan kebudayaan. Problem serius akan dihadapi oleh bangsa ini bila upaya formalisasi agama yang berkaitan dengan isu seksualitas perempuan melalui regulasi negara berhasil diwujudkan.

Sila kelima Pancasila yang berbunyi "Keadilan sosial bagi seluruh rakyat Indonesia" sesungguhnya menjamin bahwa seluruh rakyat Indonesia berhak memiliki posisi yang setara dan tidak 
memandang mana laki-laki dan perempuan. Harusnya landasan ini juga bisa menjadi dasar untuk memajukan seksualitas perempuan pada posisi semestinya. Perjuangan seksualitas perempuan di negara ini menghadapi babak yang baru. Babak dan ketegangan baru lebih tepatnya. Bila selama ini berhadapan dengan budaya patriarki yang dijustifikasi oleh adat istiadat, sekarang berhadapan dengan patriarki yang di justifikasi oleh Agama.

\section{Penutup}

Tubuh perempuan disorot dan diregulasikan dalam kancah paling esensial dari laku hidup manusia [agama], melalui penertiban perilaku, pakaian, dan segmen-segmen hidup yang lain. Tafsir-tafsir agama diwacanakan secara massif tanpa celah kritis sedikit pun, untuk memberikan satu narasi tunggal tentang stereotype perempuan melalui presentasi sebagai konstruksi kultural, yakni media. Bahwa media adalah struktur yang paling berperan dalam mereproduksi cara masyarakat mendudukkan dan memandang perempuan. Cara pandang ini diadopsi untuk memperlihatkan kekuatan media dan otoritas mainstream keagamaan dalam membentuk opini yang mendukung pandangan dominan tentang perempuan.

Tubuh perempuan dikontrol agar menjalani ketundukan dan kepatuhan dengan frame patriarki, ditopang secara kokoh oleh sebuah rezim seksualitas. Pada akhirnya, dalam gerusan modernitas yang terus-menerus dipiyuh oleh kapitalisme ini, tubuh perempuan mulai kehilangan otonomi. Pada setiap laju sejarah, hal ini akan terus dimainkan sebagai ajang politik, padahal sejatinya justru menunjukkan sebuah tontonan lemah dari patriarki yang tidak pernah bisa menundukkan egonya. 
Tabrani. ZA, Saifullah Idris \& Hayati

\section{REFERENSI}

Abdullah, A., \& Tabrani ZA. (2018). Orientation of Education in Shaping the Intellectual Intelligence of Children. Advanced Science Letters, 24(11), 8200-8204. https://doi.org/10.1166/as1.2018.12523

Abdullah, A., \& ZA, T. (2018). Orientation of Education in Shaping the Intellectual Intelligence of Children. Advanced Science Letters, 24(11), 8200-8204.

Acosta, M. (2016). Paradigm Shift in Open Education and ELearning Resources as Teaching and Learning in Philippines. Jurnal Ilmiah Peuradeun, 4(2), 161-172. doi:10.26811/peuradeun.v4i2.94

AR, M., Usman, N., Tabrani ZA, \& Syahril. (2018). Inclusive Education Management in State Primary Schools in Banda Aceh. Advanced Science Letters, 24(11), 8313-8317. https://doi.org/10.1166/as1.2018.12549

Buseri, K. (2015). Epistemologi Islam dan Reformasi Wawasan Pendidikan. Jurnal Imiah Peuradeun, 3(1), 77-102.

Chalim, A. (2018). Effect of Job-Insecurity, Organizational Commitment, Job Satisfaction on Turnover Intention: A Case Study of Newcomer Lecturers at Private Islamic Universities in East Java Province, Indonesia. Jurnal Ilmiah Peuradeun, 6(2), 199-214. doi:10.26811/peuradeun.v6i2.284

Christina Siwi Handayani, Gadis Arivia, dkk. (2013). Subyek yang Dikekang; Pengantar ke Pemikiran Julia Kristeva, Simone de Beauvoir Michel Foucault, Jacques Lacan, Jakarta: Komunitas Salihara.

Damanhuri, D. (2016). Reconstruction of Matan Hadith Understanding About Women Position in Household. Jurnal Ilmiah Peuradeun, 4(2), 239-256. doi:10.26811/peuradeun.v4i2.101

Fabretti, V., \& Di Paola, N. (2017). The Relations Between Religion and Politics in European Education Systems. Jurnal Ilmiah Peuradeun, 5(2), 225-236.

Fadli, F., Prestwich, A., \& Sykes-Muskett, B. (2018). Assessing Mediating Effect of Motivation Types on Competition Intervention For Physically Inactive Adults. Jurnal Ilmiah 
Peuradeun, 6(1), 1-16. doi:10.26811/peuradeun.v6i1.156

Faruqi, Y. M. (2015). Role of Muslim Intellectuals in the Development of Scientific Thought. Jurnal Ilmiah Peuradeun, 3(3), 451-466.

Foucault, M. (2002). Kuasa/Pengetahuan, Yudi Santosa (penerj.), Yogyakarta: Bentang Budaya.

Hughes, K., \& Batten, L. (2016). The Development of Social and Moral Responsibility in Terms of Respect for the Rights of Others. Jurnal Ilmiah Peuradeun, 4(2), 147-160. doi:10.26811/peuradeun.v4i2.93

Idris, S., \& Tabrani ZA. (2017). Realitas Konsep Pendidikan Humanisme dalam Konteks Pendidikan Islam. Jurnal Edukasi: Jurnal Bimbingan Konseling, 3(1), 96-113. https://doi.org/10.22373/je.v3i1.1420

Idris, S., Tabrani ZA, \& Sulaiman, F. (2018). Critical Education Paradigm in the Perspective of Islamic Education. Advanced Science Letters, 24(11), 8226-8230. https://doi.org/10.1166/asl.2018.12529

Jeremy R. Carette (ed.). (2011). Agama, Seksualitas, Kebudayaan; Esai, Kuliah, dan Wawancara Terpilih Michel Foucault, Yogyakarta: Jalasutra.

Kaylene, P., \& Rosone, T. (2016). Multicultural Perspective on the Motivation of Students in Teaching Physical Education. Jurnal Ilmiah Peuradeun, 4(1), 115-126. doi:10.26811/peuradeun.v4i1.90

Lewis, M., \& Ponzio, V. (2016). Character Education as the Primary Purpose of Schooling for the Future. Jurnal Ilmiah Peuradeun, 4(2), 137-146. doi:10.26811/peuradeun.v4i2.92

Musradinur, \& Tabrani ZA. (2015). Paradigma Pendidikan Islam Pluralis Sebagai Solusi Integrasi Bangsa (Suatu Analisis Wacana Pendidikan Pluralisme Indonesia). 1st Annual International Seminar on Education 2015, 77-86. Banda Aceh: FTK Ar-Raniry Press.

Muttaqin, F. (2015). Early Feminist Consciousness and Idea Among Muslim Women in 1920s Indonesia. Jurnal Ilmiah Peuradeun, 3(1), 19-38.

Patimah, S., \& Tabrani ZA. (2018). Counting Methodology on 
Educational Return Investment. Advanced Science Letters, 24(10), 7087-7089. https://doi.org/10.1166/asl.2018.12414

Siswanto, R., Sugiono, S., \& Prasojo, L. (2018). The Development of Management Model Program of Vocational School Teacher Partnership with Business World and Industry Word (DUDI). Jurnal Ilmiah Peuradeun, 6(3), 365-384. doi:10.26811/peuradeun.v6i3.322

Tabrani ZA \& Murziqin, R. (2015). Political Education in Maturation Democracy in Indonesia. British Journal of Political Science, 45 (1), 215-226

Tabrani ZA, \& Masbur. (2016). Islamic Perspectives on the Existence of Soul and Its Influence in Human Learning (A Philosophical Analysis of the Classical and Modern Learning Theories). JURNAL EDUKASI: Jurnal Bimbingan Konseling, 1(2), 99-112. Retrieved from http://jurnal.arraniry.ac.id/index.php/cobaBK/article/view/600

Tabrani ZA. (2009). Ilmu Pendidikan Islam (antara Tradisional dan Modern). Kuala Lumpur: Al-Jenderami Press.

Tabrani ZA. (2011a). Dynamics of Political System of Education Indonesia. International Journal of Democracy, 17(2), 99-113.

Tabrani ZA. (2011b). Nalar Agama dan Negara dalam Perspektif Pendidikan Islam. (Suatu Telaah Sosio-Politik Pendidikan Indonesia). Millah Jurnal Studi Agama, 10(2), 395-410.

Tabrani ZA. (2012a). Future Life of Islamic Education in Indonesia. International Journal of Democracy, 18(2), 271-284.

Tabrani ZA. (2013a). Modernisasi Pengembangan Pendidikan Islam (Suatu Telaah Epistemologi Pendidikan). Serambi Tarbawi, 1(1), 65-84.

Tabrani ZA. (2013b). Pengantar Metodologi Studi Islam. Banda Aceh: SCAD Independent.

Tabrani ZA. (2013c). Urgensi Pendidikan Islam dalam Pemberdayaan Masyarakat. Jurnal Sintesa, 13(1), 91-106.

Tabrani ZA. (2014a). Dasar-Dasar Metodologi Penelitian Kualitatif. Yogyakarta: Darussalam Publishing.

Tabrani ZA. (2014b). Islamic Studies dalam Pendekatan Multidisipliner (Suatu Kajian Gradual Menuju Paradigma Global). Jurnal Imiah Peuradeun, 2(2), 211-234. 
Tabrani ZA, Saifullah Idris \& Hayati

Tabrani ZA. (2014c). Isu-Isu Kritis dalam Pendidikan Islam Perspektif Pedagogik Kritis. Jurnal Mmiah Islam Futura, 13(2), 250-270. https://doi.org/10.22373/jiif.v13i2.75

Tabrani ZA. (2015a). Arah Baru Metodologi Studi Islam. Yogyakarta: Penerbit Ombak.

Tabrani ZA. (2015b). Persuit Epistemology of Islamic Studies (Buku 2 Arah Baru Metodologi Studi Islam). Yogyakarta: Penerbit Ombak.

Tabrani ZA. (2016a). Perubahan Ideologi Keislaman Turki (Analisis Geo-Kultur Islam dan Politik Pada Kerajaan Turki Usmani). JURNAL EDUKASI: Jurnal Bimbingan Konseling, 2(2), 130146. https://doi.org/10.22373/je.v2i2.812

Tabrani ZA. (2016b). Transformasi Teologis Politik Demokrasi Indonesia (Telaah singkat Tentang Masyarakat Madani dalam Wacana Pluralisme Agama di Indonesia). Al-Ijtima ${ }^{-}$International Journal of Government and Social Science, 2(1), 41-56.

Tabrani ZA. (2017). Menggugat Logika Nalar Rasionalisme Aristoteles. Yogyakarta: Mizan.

Usman, N., AR, M., Murziqin, R., \& Tabrani ZA. (2018). The Principal's Managerial Competence in Improving School Performance in Pidie Jaya Regency. Advanced Science Letters, 24(11), 8297-8300. https://doi.org/10.1166/as1.2018.12545

Verlo, M. (2015). Religion, Church, Intimate Citizenship and Gender Equality. Jurnal Ilmiah Peuradeun, 3(1), 55-76.

Walidin, W., Idris, S., \& Tabrani ZA. (2015). Metodologi Penelitian Kualitatif \& Grounded Theory. Banda Aceh: FTK Ar-Raniry Press.

Warisno, A., \& Tabrani ZA. (2018). The Local Wisdom and Purpose of Tahlilan Tradition. Advanced Science Letters, 24(10), 70827086. https://doi.org/10.1166/asl.2018.12413 